\title{
Hemodynamic effects of lipid emulsion after local anesthetic intoxication may be due to a direct effect of fatty acids on myocardial voltage-dependent calcium channels
}

\author{
Jean-Pierre Pennec, PhD • Maité Guillouet • \\ Fabrice Rannou, MD - Charles C. Arvieux, MD, PhD • \\ Gildas Gueret, MD, PhD
}

Received: 3 June 2010/Accepted: 21 June 2010/Published online: 11 August 2010

(C) Canadian Anesthesiologists' Society 2010

\section{To the Editor,}

We read with great interest the review article by Dillane et al. on local anesthetic systemic toxicity. ${ }^{1}$ The authors considered two hypotheses regarding the mechanism of action of lipid emulsions. The first hypothesis was pharmacological, wherein a circulating lipid sink extracts lipophilic local anesthetic from either plasma or tissues. The second hypothesis was metabolic, invoking reversion of the local anesthetic inhibition of the myocardial fatty acid oxidation. We suggest that a third mechanism could be involved, i.e., a direct stimulation of the voltage-gated calcium channels $\left(\mathrm{Ca}_{\mathrm{V}}\right)$ of cardiomyocytes by long-chain fatty acids. ${ }^{2}$ Huang et al. showed that long-chain fatty acids could activate myocardial $\mathrm{Ca}_{\mathrm{V}}$ directly and then induce a dose-dependent increase of calcium current. Intralipid ${ }^{\circledR}$ solution contains mainly oleic and linoleic acids $(23.5 \%$ and $53 \%$, respectively, according to laboratory data) that induce a strong and early increase (within two minutes) of the calcium current in the cardiomyocytes. ${ }^{2}$ In an isolated rat heart model perfused with L-bupivacaine solution, Stehr et al. observed a rapid increase in myocardial contractility and left ventricular systolic pressure after administration of a lipid emulsion. ${ }^{3}$ They attributed this response primarily to a direct inotropic effect, even though a local anesthetic plasma-binding effect of lipids could not be excluded. Direct activation of the $\mathrm{Ca}_{\mathrm{V}}$ by fatty acids could at last partly explain the early effects of lipid emulsions on myocardial toxicity of local anesthetics, as has been proposed for calcium channel blocking agents. ${ }^{4,5}$

Competing interests None declared.

\section{References}

1. Dillane D, Finucane BT. Local anesthetic systemic toxicity. Can J Anesth 2010; 57: 368-80.

2. Huang JM, Xian H, Bacaner M. Long-chain fatty acids activate calcium channels in ventricular myocytes. Proc Natl Acad Sci U S A 1992; 89: 6452-6.

3. Stehr SN, Ziegeler JC, Pexa A, et al. The effects of lipid infusion on myocardial function and bioenergetics in 1-bupivacaine toxicity in the isolated rat heart. Anesth Analg 2007; 104: 186-92.

4. Cottrel M, Nguyen BV, Guillouet $M$, et al. Les émulsions lipidiques dans les intoxications aux agents stabilisants de membrane. Réanimation 2008; 17: 670-5.

5. Gueret G, Pennec JP, Arvieux CC. Hemodynamic effects of intralipid after verapamil intoxication may be due to a direct effect of fatty acids on myocardial calcium channels. Acad Emerg Med 2007; 14: 761.

Editor's Note: The authors of the review article: Can J Anesth 2010; 57: 368-80, respectfully declined an invitation to submit a reply to the above Letter to the Editor.

J.-P. Pennec, PhD · M. Guillouet · F. Rannou, MD .

C. C. Arvieux, MD, PhD - G. Gueret, MD, PhD ( $\varangle)$

Faculté de Médecine et des Sciences de la Santé,

Université de Brest, Brest, France

e-mail: gildas.gueret@chu-brest.fr 